\title{
HEALTH SERVICES VOCATIONAL SCHOOL STUDENTS' KNOWLEDGE LEVELS OF ON PARASITIC DISEASES
}

\section{Sağlık Hizmetleri Meslek Yüksekokulu Öğrencilerinin Paraziter Hastalıklar Hakkındaki Bilgi Düzeyleri}

\author{
Abdurrahman EKICI $\dot{I}^{1}$ (D) Şehriban YÜREKTÜRK ${ }^{2}$ (D) Sadi ELASAN ${ }^{3}$ (1) \\ Ahmet Galip HALIDI I I Sinan KARAKUS ${ }^{5}$ (D) Selahattin AYDEMIR ${ }^{6}$ (D) \\ Maksut SAHIN ${ }^{7}$ (D) Muhammed YASUL ${ }^{8}$ Hasan YILMAZ ${ }^{9}$ (D) \\ ${ }_{1,3,6,7,8,9}$ Van Yüzüncü Yll University, Faculty of Medicine, Van \\ ${ }^{2}$ Van Yüzüncü Yıl University, Vocational School of Health Services, Van \\ ${ }^{4}$ Muş Alparslan University, Bulanik Vocational School, Muş \\ ${ }^{5}$ Turkish Red Crescent Blood Donor Center, Van
}

Geliş Tarihi / Received: 14.09.2021

Kabul Tarihi / Accepted: 13.12.2021

\begin{abstract}
In this study, it has been aimed to determine the knowledge level of the students of Van Yuzuncu Yil University Health Services Vocational School, who will serve as the health personnel of the future, about parasitic diseases, prevention and control measures from these diseases. A total of 587 students, comprising 418 (71.2\%) females and 169 (28.8\%) males, studying at Van Yüzüncü Y1l University Health Services Vocational School, were included in the study. The questions in the questionnaire were arranged in three groups, as those about parasitic diseases, transmission routes of these diseases, and prevention and treatment. Cronbach alpha coefficients were calculated within the scope of the reliability analysis of the questionnaire questions. The Cronbach alpha values for the domains of Knowledge Level About Parasitic Diseases, Knowledge Level About the Transmission of Parasitic Diseases, and Knowledge Level About the Prevention and Treatment of Parasitic Diseases were determined as $0.647(64.7 \%), 0.707(70.7 \%)$, and $0.566(56.6 \%)$, respectively. A statistically significant difference was found between the departments included in the study in terms of the level of knowledge about parasitic diseases $(\mathrm{P}<0.05)$. A statistically significant difference was found between the departments in the evaluation made between the level of knowledge about the prevention and treatment of parasitic diseases and the personal characteristics of the students $(\mathrm{P}<0.05)$. As the result, it was observed that the students participating in the study did not have sufficient knowledge about parasitic diseases.
\end{abstract}

Keywords: Health, Parasite, Prevention, Transmission.

\section{ÖZ}

$\mathrm{Bu}$ çalışmada, geleceğin sağlık personeli olarak hizmet verecek olan Van Yüzüncü Yıl Üniversitesi Sağlık Hizmetleri Meslek Yüksekokulu öğrencilerinin paraziter hastalıklar, bu hastalıklardan korunma ve kontrol önlemleri hakkındaki bilgi düzeylerinin belirlenmesi amaçlanmıştır. Van Yüzüncü Yıl Üniversitesi Sağlık Hizmetleri Meslek Yüksekokulunda okuyan 418’i (\%71.2) k1z, 169’u (\%28.8) erkek, toplam 587 öğrenci çalışamaya dâhil edildi. Anketteki sorular, paraziter hastalıklar, bu hastalıkların bulaş yolları, koruma ve tedavi hakkında olmak üzere üç grup olarak ayarlandı. Anket sorularının güvenirlik (reliability) analizi kapsamında Cronbach's Alpha katsayıları hesaplandı. "Paraziter Hastalıklara İlişkin Bilgi Düzeyi”, "Paraziter Hastalıkların Bulaş Yollarına İlişkin Bilgi Düzeyi” ve "Paraziter Hastalıklardan Korunma ve Tedaviye İlişkin Bilgi Düzeyi” sorularına ait Cronbach's Alpha değerleri sirasıla 0.647 (\%64.7), 0.707 (\%70.7), 0.566 (\%56.6) olarak saptandı. Çalışmaya dâhil edilen bölümler arasında, paraziter hastalıklara ilişkin bilgi düzeyi yönünden, istatistiksel olarak anlamlı bir fark bulundu $(\mathrm{p}<0.05)$. Paraziter hastalıklardan korunma ve tedaviye ilişkin bilgi düzeyi ile öğrencilerin kişisel özellikleri arasında yapılan değerlendirmede bölümler arasında istatistiksel olarak anlamlı bir fark bulundu $(\mathrm{p}<0.05)$. Sonuç olarak çalışmaya katılan öğrencilerin, paraziter hastalıklar hakkında yeterli bilgiye sahip olmadıkları gözlemlendi.

Anahtar kelimeler: Bulaş, Korunma, Parazit, Sağlık. 


\section{INTRODUCTION}

Parasitic diseases, which are known to cause disease in humans and animals, have been considered as an important public health problem throughout history. Parasitic diseases are more common in situations as insufficient infrastructure, low socio-economic status and education level, and non-compliance with hygiene rules, especially in developing and underdeveloped countries. (Börekçi \& Uzel, 2009; Çayc1, Hacıeminoğlu \& Birinci, 2017; Değerli, Özçelik , \& Çeliköz, 2005; Sarı \& Demirbağ, 2019).

Studies have reported that parasitic diseases affect approximately 4 billion people worldwide. It was reported that in 2013, approximately 584,000 people died due to malaria, and millions of people died due to chagas, African trypanosomiasis, strongyloidiasis, amebiasis, leishmaniasis, ascariasis, and schistosomiasis diseases. The clinic of the parasitic disease usually differ according to the immune status of the host. In healthy people, some non-pathogenic parasites can cause very severe infections in cases such as immune system deficiency or the use of immunosuppressive drugs. Parasitic diseases, which are usually asymptomatic, can become chronic and continue for a long time. Thus, these diseases cause physical and mental development problems in children and give rise to economic losses by adult work loss (Balc1, Türk, Polat, \& Erbil, 2009; Doğan, Akdaş, Gitmez, \& Ünsal; 2012).

Parasites, which cause disease, enter the human body through; contaminated water and food, respiration, blood transfusion, organ transplantation or placenta. To determine the prevention and treatment strategies in parasitic diseases, it is very important to have information about these parasites and know the transmission routes to humans and animals. It is believed that the loss of work force and treatment costs can be reduced with awareness of society and the implementation of preventive methods (Çayc1 et al., 2017; Doğan et al., 2012; Demir, Y1ldız, \& Yürektürk,2020).

As in other infectious diseases, education is at the top of the list in the prevention of parasitic diseases. The level of knowledge and attitudes of the personnel, working in healthrelated fields, about parasitic diseases is extremely important, and it is known that they have an active role and responsibility in the prevention methods to be developed against these diseases (Canan \& Demirbağ, 2019; Demir et al., 2020; Gülmez, Sarıbaş, Akyön, \& Ergüven; 2013).

In this study, it was aimed to determine the knowledge level of the students of Van Yüzüncü Y1l University Vocational School of Health Services, who will serve as the health personnel of the future about prevention and control on parasitic diseases. 


\section{MATERIAL AND METHOD}

This study was carried out between 01.12.2020-01.01.2021. A total of 587 students from Van Yüzüncü Y1l University Vocational School of Health Services Departments of Anesthesia, Child Development, Dialysis, Disabled Care and Rehabilitation, Pharmacy Services, First and Emergency Aid, Radiotherapy, Medical Documentation and Secretarial, Medical Laboratory, and Medical Imaging, Elderly Care Services were included. The questionnaires were prepared by the researchers using the literature in accordance with the purpose of the study (Canan \& Demirbağ, 2019; Doğan et al., 2012). In the questionnaire, there were questions about the personal characteristics of the students, in which descriptive information was questioned (Table). Three groups, consisting of; 20 questions for knowledge levels about parasitic diseases, 16 questions about knowledge levels of transmission routes of these diseases, and 11 questions about knowledge levels of prevention and treatment, were formed. To make the assessment more objective, the students' answers were scored.

\section{Statistical analysis}

In calculating the sample size, the power of each variable was taken as at least $80 \%$ and the type 1 error was $5 \%$. Whether the continuous measurements in the study were normally distributed or not was checked using the Kolmogorov-Smirnov ( $\mathrm{n}>50)$ and SkewnessKurtosis tests. Parametric tests were applied as the measurements were normally distributed. Descriptive statistics as; mean, standard deviation, minimum and maximum were used for the continuous variables, and numbers and percentage were used for the categorical variables. Cronbach Alpha coefficients were calculated within the scope of the reliability analysis of the questionnaire questions. Comparisons were made by calculating the total of the correct answers for the questions on Knowledge Levels on Parasitic Diseases. Independent t-test and one-way analysis of variance (ANOVA) were used to compare the knowledge level scores according to personal characteristics. The Duncan test was used to identify different groups following ANOVA. Statistical significance (a) was accepted as $5 \%$ in the calculations and IBM SPSS Statistics for Windows 24.0 (IBM Corp., Armonk, NY, USA) was used for the analyses.

\section{RESULTS}

The Cronbach alpha value which is related with the questions on Knowledge Level of Parasitic Diseases was found $0.647(64.7 \%)$ and the same value for the questions on 
Knowledge Level of the Transmission of Parasitic Diseases was found 0.707 (70.7\%). It was found that the reliability of these questions according to the Cronbach Alpha value was at a significant level (Table 1). The Cronbach Alpha value for the questions on Knowledge Level of Prevention and Treatment of Parasitic Diseases was 0.566 (56.6\%).

Table 1. Reliability Analysis Results of the Survey Questions

\begin{tabular}{lcc}
\hline \multicolumn{1}{c}{ Survey section } & \multicolumn{2}{c}{ Reliability Statistics } \\
\cline { 2 - 3 } & Cronbach's Alpha & N of Items \\
\hline Level of Knowledge of Parasitic Diseases & 0.647 & 14 \\
\hline $\begin{array}{l}\text { Level of Knowledge on Transmission Routes of Parasitic } \\
\text { Diseases }\end{array}$ & 0.707 & 9 \\
\hline $\begin{array}{l}\text { Level of Knowledge on Prevention and Treatment of Parasitic } \\
\text { Diseases }\end{array}$ & 0.566 & 34 \\
\hline Level of Knowledge on General Parasitic Diseases & & 0.826 \\
\hline
\end{tabular}

A total of 587 students, comprising 418 (71.2\%) females and 169 (28.8\%) males, participated in this study (Table 2). The knowledge levels of the students about parasitic diseases were evaluated statistically. When the Level of Knowledge on Parasitic Diseases was compared according to their personal characteristics (Table 3), it was observed that there was a statistically significant difference between the departments $(\mathrm{P}<0.05)$. Accordingly, the students of the Anesthesia and First and Emergency Aid departments made the difference by getting higher scores than the other departments. It was determined that Anesthesia and First and Emergency Aid departments had more knowledge about parasitic diseases than other departments. Similarly, it was determined that students between the ages of 21-30 had more parasitic disease knowledge than younger students $(\mathrm{P}<0.05)$. In the evaluation made according to gender, it was determined that male students were more knowledgeable than female students and there was a statistically significant difference $(\mathrm{P}<0.05)$. It was determined that the students who took the parasitology course had more parasitic disease knowledge than the students who did not take the course $(\mathrm{P}<0.05)$.

Table 2. General Descriptive Statistics of Personal Characteristics

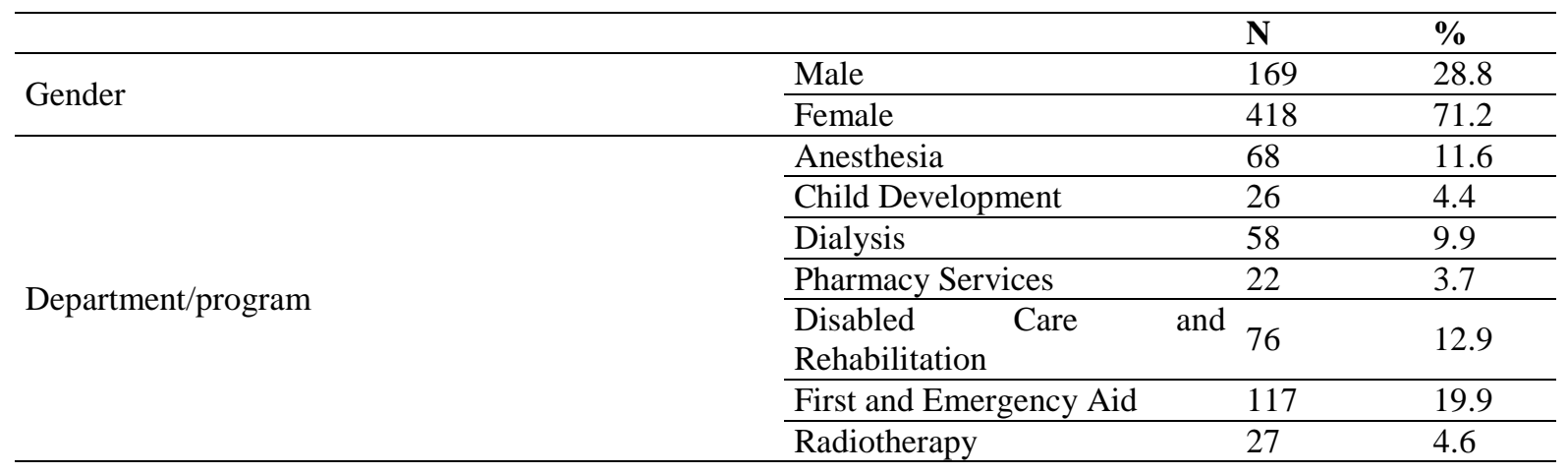




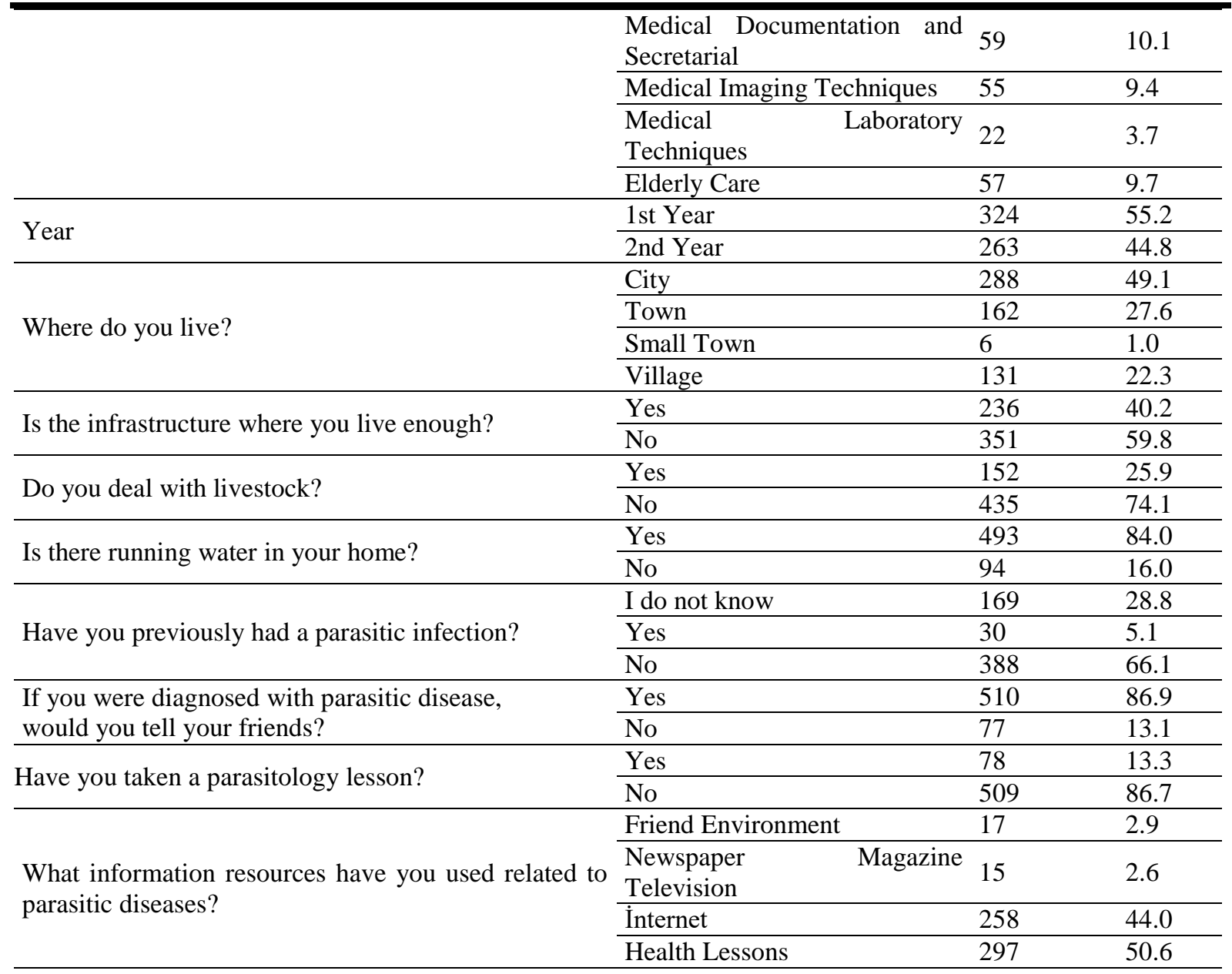

Table 3. Comparison Results of Knowledge of Parasitic Diseases According to Personal Characteristics

\begin{tabular}{|c|c|c|c|c|}
\hline Knowledge of Parasitic Diseases & & mean & Std.Dev. & $* \mathrm{p}$. \\
\hline \multirow[t]{2}{*}{ 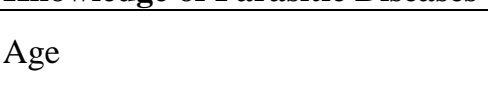 } & $18-20$ years & 7.21 & 2.80 & \multirow{2}{*}{0.001} \\
\hline & 21-30 years & 7.96 & 2.56 & \\
\hline \multirow{2}{*}{ Gender } & Boy & 7.92 & 2.83 & \multirow{2}{*}{0.032} \\
\hline & Woman & 7.39 & 2.66 & \\
\hline \multirow{11}{*}{ Department/Program } & Anaesthesia & 8.43 & 2.22 & \multirow{11}{*}{0.001} \\
\hline & Child Development & 6.35 & 2.84 & \\
\hline & Dialysis & 7.90 & 2.60 & \\
\hline & Pharmacy Services & 6.64 & 2.61 & \\
\hline & $\begin{array}{l}\text { Disabled Care and } \\
\text { Rehabilitation }\end{array}$ & 7.09 & 2.47 & \\
\hline & $\begin{array}{l}\text { First and Emergency } \\
\text { Aid }\end{array}$ & 8.16 & 2.57 & \\
\hline & Radiotherapy & 6.96 & 2.89 & \\
\hline & $\begin{array}{l}\text { Medical Documentation } \\
\text { and Secretarial }\end{array}$ & 6.86 & 2.80 & \\
\hline & $\begin{array}{l}\text { Medical Imaging } \\
\text { Techniques }\end{array}$ & 7.87 & 3.01 & \\
\hline & $\begin{array}{l}\text { Medical Laboratory } \\
\text { Techniques }\end{array}$ & 7.68 & 2.63 & \\
\hline & Elderly care & 6.91 & 2.99 & \\
\hline \multirow{3}{*}{ Your Mother's Education Level } & Not Literate & $7.52^{\mathrm{a}}$ & 2.75 & \multirow{3}{*}{0.022} \\
\hline & Primary school & $7.47^{\mathrm{a}}$ & 2.65 & \\
\hline & Middle School & $7.86^{\mathrm{a}}$ & 2.86 & \\
\hline
\end{tabular}




\begin{tabular}{lllll}
\hline & High school & $8.44^{\mathrm{a}}$ & 1.87 \\
\cline { 2 - 4 } & University & $5.20^{\mathrm{b}}$ & 3.26 \\
\hline \multirow{2}{*}{ Is there running water in your home? } & Yes & 7.66 & 2.64 & \multirow{2}{*}{0.014} \\
\cline { 2 - 4 } & No & 6.90 & 3.06 & \\
\hline \multirow{2}{*}{ Have you taken a parasitology lesson? } & Yes & 8.26 & 2.95 & \multirow{2}{*}{0.012} \\
\cline { 2 - 4 } & No & 7.43 & 2.67 &
\end{tabular}

Std. Dev.: standard deviation, ${ }^{\text {a }}$ significant, ${ }^{\text {b }}$ no significant

There was no statistically significant difference between the level of knowledge about the transmission routes of parasitic diseases and the personal characteristics of the students $(\mathrm{P}>0.05)$.

A statistically significant difference was found in the evaluation made between the departments according to the level of knowledge about prevention and treatment of parasitic diseases (Table 4) and the personal characteristics of the students $(\mathrm{P}<0.05)$. Accordingly, the students of the Department of Child Development received lower scores, and the students of the Departments of Anesthesia, Dialysis, First and Emergency Aid received higher scores. Similarly, it was determined that those who were diagnosed with a parasitic disease and shared this fact with those around them, and those who took a parasitology course, had more knowledge $(\mathrm{P}<0.05)$.

Table 4. Comparison Results of the Level of Knowledge on Prevention and Treatment of Parasitic Diseases According to Personal Characteristics

\begin{tabular}{|c|c|c|c|c|}
\hline \multicolumn{2}{|c|}{$\begin{array}{l}\text { Level of Knowledge on Prevention and Treatment of Parasitic } \\
\text { Diseases }\end{array}$} & mean & Std.Dev. & $*$ p. \\
\hline \multirow{11}{*}{ Department/Program } & Anaesthesia & $5.09^{\mathrm{a}}$ & 1.55 & \multirow{11}{*}{0.009} \\
\hline & Child Development & $3.46^{b}$ & 2.02 & \\
\hline & Dialysis & $4.97^{\mathrm{a}}$ & 1.85 & \\
\hline & Pharmacy Services & $4.41^{\mathrm{a}}$ & 1.94 & \\
\hline & Disabled Care and Rehabilitation & $4.43^{\mathrm{a}}$ & 1.81 & \\
\hline & First and Emergency Aid & $4.83^{\mathrm{a}}$ & 1.92 & \\
\hline & Radiotherapy & $4.30^{\mathrm{a}}$ & 2.25 & \\
\hline & $\begin{array}{l}\text { Medical Documentation. and the } \\
\text { Secretariat }\end{array}$ & $4.12^{\mathrm{a}}$ & 2.13 & \\
\hline & Medical Imaging Techniques & $4.71^{\mathrm{a}}$ & 1.81 & \\
\hline & Medical Laboratory Techniques & $4.77^{\mathrm{a}}$ & 1.93 & \\
\hline & Elderly care & $4.39^{\mathrm{a}}$ & 2.06 & \\
\hline \multirow{5}{*}{$\begin{array}{l}\text { Your Mother's Education } \\
\text { Level }\end{array}$} & Not Literate & $4.54^{\mathrm{a}}$ & 1.94 & \multirow{5}{*}{0.001} \\
\hline & Primary school & $4.73^{\mathrm{a}}$ & 1.84 & \\
\hline & Middle School & $4.62^{\mathrm{a}}$ & 2.13 & \\
\hline & High school & $5.00^{\mathrm{a}}$ & 1.54 & \\
\hline & University & $2.10^{\mathrm{b}}$ & 1.60 & \\
\hline \multirow{2}{*}{$\begin{array}{l}\text { If you were diagnosed with } \\
\text { a parasitic disease, would } \\
\text { you share it with your } \\
\text { friends? }\end{array}$} & Yes & 4.68 & 1.89 & \multirow[b]{2}{*}{0.004} \\
\hline & No & 4.00 & 2.10 & \\
\hline
\end{tabular}

Std. Dev.: standard deviation, ${ }^{\text {a }}$ significant, ${ }^{\text {b }}$ no significant 


\section{DISCUSSION}

It is known that parasitic diseases are an important health problem in Turkey, as well as all over the world. It is also known that among the common causes of parasitic diseases are the inability of diagnosis and treatment of parasitic diseases, lack of knowledge about prevention possibilities and necessary precautions, low socioeconomic status, and insufficient infrastructure in rural areas (Aytar et al., 2015; Cengiz, Beyhan, Çiçek, \& Y1lmaz, 2015).

The importance of raising generations with a good knowledge of public health for a healthy future is known. Knowing the level of knowledge about parasitic diseases, the attitudes of the students who will serve in various health fields, and their attitudes toward prevention and treatment would be helpful. Although parasites occupy an important place in the environment we live in, both in terms of biodiversity and high prevalence, there are very few studies that have aimed to determine the level of knowledge about parasitic diseases (Demir et al., 2020; Eraslan, 2011; Sar1 \& Demirbağ, 2019).

In a study conducted in Saudi Arabia to determine knowledge level about parasitic diseases among university students according to various social variables, it was stated that one-third of the students did not have sufficient knowledge. In a study conducted in China to determine both parasitic diseases and the knowledge level about these diseases with 759 participants, and it was determined that the level of knowledge about parasitic diseases was low (Doğan et al., 2012; Yan-Li et al., 2017; Zakai, 2007).

In a study conducted by Sar1 et al. (2019), it was determined that healthcare professionals working in the pediatric service did not have sufficient knowledge about parasitic diseases. In a study conducted in Çorum, the level of knowledge of students about hydatid cysts was examined and it was determined that approximately one-third of the students knew about this disease (Y1lmazel, Yapar, \& Özkan, 2019). In another study conducted by Doğan et al (2012), the level of knowledge of university students about parasitic diseases were investigated. It was stated that 159 (69.4\%) of 229 students had sufficient knowledge.

The survey data of 587 Vocational School of Health Services students included in this study were evaluated, and as a result, it was determined that the students did not have sufficient knowledge about parasitic diseases, transmission routes of these diseases, prevention, or control. The training given to the students has a critical role in the control of the spread of the disease by raising awareness in the control and protection of parasitic diseases. It was concluded that education is very important in the reduction of parasitic 
diseases and more education programs should be planned to update the information and bring it to an applicable level.

In a study conducted by Doğan et al. (2012), it was stated that the level of knowledge of female students about parasitic diseases was higher than that of male students, and this was because the knowledge acquisition behavior of the female students was higher than that of the boys. Sar1 et al. (2019), in their study evaluated the knowledge level of university students about infectious diseases and stated that knowledge level female students was higher than that of the male students. In another study, the knowledge levels of the students about health were compared based on their year of study, and it was determined that there was a significant difference between the knowledge levels of the second- and third-year students (Aytar et al., 2015; Doğan et al., 2012; Eraslan, 2011). In this study, when comparing the level of knowledge on parasitic diseases between gender and age groups, it was determined that male students had more information than female students, and students between 21-30 years of age had more information than students in the younger age group. These data were inconsistent with the literature (Aytar et al., 2015; Demir et al., 2020; Eraslan, 2011). Most of the parasitic diseases are arise out of zoonotic source. The awareness in men is higher by the reason of they are occupied in animal husbandry more than woman. In addition, since the level of awareness and knowledge may increase with age due to exposure to parasitic diseases, the knowledge level of students between 21-30 years of age is higher.

With the determination of the knowledge level of the departments of Anesthesia, Child Development, Dialysis, Disabled Care and Rehabilitation, Pharmacy Services, First and Emergency Aid, Radiotherapy, Medical Documentation and Secretariat, Medical Laboratory, Medical Imaging, Elderly Care Services about parasitic diseases, and the prevention and treatment of parasitic diseases in the related evaluation, it was determined that the knowledge level of the students in the Department of Anesthesiology was higher than that of the students in the other departments. It was determined that the students in the First and Emergency Aid and Dialysis program were at the top of the list of knowledge levels, while the students in the Child Development program were ranked last. It is thought that this difference was because Infectious Diseases and Microbiology courses are included in the curriculum of Anesthesia, Dialysis, First and Emergency Aid programs. It was concluded that the level of knowledge was lower due to the absence of these courses in the curriculum of the Department of Child Development. 
Unsafe and inadequate drinking water, inadequate sanitation, and poor hygiene account for $7 \%$ of the global burden of disease and $19 \%$ of child deaths worldwide (Aschale et al., 2021). In this survey study, it was determined that the infrastructure in the houses of 351 students was insufficient and the drinking water in the houses of 94 students was not connected to the city network. It is believed that this may pose a great risk in terms of parasitic diseases. When the sources of information about parasitic diseases were examined, it was seen that 297 (50.6\%) of the students obtained it from health-related courses, 258 (44\%) obtained it from the internet, 15 (2.5\%) obtained it from television channels, newspapers, and magazines, and 17 (2.9\%) obtained it from their friends. Of the students, 509 (86.7\%) stated that they did not take a parasitology course and $510(86.9 \%)$ stated that when they were diagnosed with a parasitic disease, they understood that they had to share this fact with those around them. In this study, it was determined that the level of knowledge of those who took parasitology courses was high in evaluating both the level of knowledge about parasitic diseases and the level of general knowledge according to their personal characteristics. The aim of health education is to create behavioral change that will enable individuals to protect and improve their health and benefit from treatment opportunities (Aytar et al., 2015; Gökkoca, 2001). It has been stated that the courses given in schools will contribute to behavioral change in the control and prevention of parasitic diseases as well as in infectious diseases. In addition, when comparing the level of knowledge about the prevention and treatment of parasitic diseases and general knowledge levels, it was determined that the level of knowledge of the students who were diagnosed with a parasitic disease and stated that they could share this fact with those around them was high. It was seen that students with a high awareness of parasitic diseases did not hide the fact that they had these diseases and shared this fact with those around them.

As a result, it was observed that the students who participated in the study and who will serve the society as health personnel in the future do not have enough knowledge about parasitic diseases. It is necessary to develop effective education and training strategies for the prevention of parasitic diseases, prevention, treatment and increasing the awareness of students. It is thought that education programs should be planned in hospitals and community health centers as well as schools to include parasitic diseases in the curriculum of schools and to make current knowledge applicable. 
Ethics Committee Approval: Ethics committee approval was received for this study from Van Yüzüncü Y1l University Non-Invasive Clinical Research Ethics Committee (ethics committee date and no: 11/12/2020-2020/10-10)

Peer-review: Externally peer-reviewed.

Author Contributions:

Concept-A.E., A.G.H., Design- A.E., A.G.H, Ş.Y., Literature Search-Ş.Y., S.A., M.Ş., Data Collection and Processing- Ş.Y., S.E., S.K., A.E., M.Y., M.Ş., Analysis or Interpretation- S.E., A.E., H.Y., Writing-A.E., Ş.Y., S.A.

Conflict of Interest: No conflict of interest was declared by the authors.

Financial Disclosure: The authors declared that this study hasn't received no financial support.

\section{REFERENCES}

Aschale, A., Adane, M., Getachew, M., Faris, K., Gebretsadik, D., Sisay, T., ... Kloos, H. (2021). Water, sanitation, and hygiene conditions and prevalence of intestinal parasitosis among primary school children in Dessie City, Ethiopia. PloS one, 16(2), e0245463.

Aytar, A. A., Öztürk, E. C., Göçmen, Ş., Çalışkan, E., Özaras, F., Avcıŏ̆lu, F., ... Yavuz, M. T (2015). Investigation of intestinal parasites and level of hygiene knowledge of school students. Turkiye Parazitol Derg, 39, 277-285.

Balcı, Y. I., Türk, M., Polat, Y., Erbil, N. (2009). The distrubition of intestinal parasites among children in Denizli. Türkiye Parazitoloji Derg, 33(4), 298-300.

Börekçi, G., Üzel, A. (2009). The determination of intestinal parasites, physical growth and hygiene behaviors of children in the Mersin city social service child care centre, Türkiye Parazitol Derg, 33, 63-72.

Çaycı, T. Y., Hacıeminoğl, K., Birinci, A. (2017). Distribution of intestinal parasites detected in the laboratory of parasitology in Ondokuz Mayis University faculty of medicine hospital between 2014 and 2016. Journal of Health Sciences of Kocaeli University, 3(3), 6-8.

Cengiz, Z., Beyhan, Y., Çiçek, M., Yilmaz, H. (2015). Intestinal and hepatic parasites determined in a university hospital parasitology laboratory. Dicle Medical Journal, 42(3), 350-354.

Değerli, S., Özçelik, S., Çeliksöz, A. (2005). Distribution of intestinal parasites in patients admitted to Cumhuriyet University Faculty of Medicine Parasitology laboratory. Türkiye Parazitol Derg, 29(2), 1169.

Demir, C., Yıldız, H., Yürektürk, Ş. (2020). Van Yuzuncu Yıl University Vocational School of Health Services students' knowledge level on infectious diseases. Van Med J., 27(4), 458-65.

Doğan, N., Akdaş, I., Gitmez, F., Unsal, A. (2012). Knowledge level of the students in vocational school of health about parasitic diseases, Kafkas Univ Vet Fak Derg, 18, A71-A5.

Eraslan, B. (2011). Evaluation of elemantary school teachings students' candidates of about common communicable diseases behaviors of health protection. Bibad, 4(2), 17-22.

Gökkoca, Z. (2001). Sağlık eğitimi açısından temel ilkeler. Sürekli Tıp Eğitimi Dergisi, 10(10), 371-374. 
Gülmez, D., Sarıbaş, Z., Akyön, Y., Ergüven, S. (2013). The results of Hacettepe University Faculty of Medicine Parasitology Laboratory in 2003-2012: evaluation of 10 years. Turkiye Parazitol Derg, 37, 97-101.

Sarı, C., Demirbağ, B. C. (2019). Assessment of knowledge level of parasitic diseases of health professionals working in pediatric services in a university hospital. Journal of Anatolia Nursing and Health Sciences, 22(3), 161-9.

Yan-Li, G., Yong-Gen, Z., Yi-Qing, X., Hong, C., Ming-Zhen, H., Lai-Fu, L., ... Xiao-Lin, J. (2017). Investigation of major parasitic diseases and related knowledge, attitude and practice among rural residents in Liyang City. Chinese Journal Of Schistosomiasis Control, 30(1), 72-75.

Yllmazel, G., Yapar, D., Özkan, A. T. (2019). Knowledge and attitudes of nursing students about cystic hydatid in Çorum Province. Turk Hij Den Biyol Derg, 76(4), 431-40.

Zakai, H. A. (2007). Level of awareness about parasitic diseases among students, Jeddah, Saudi Arabia. Journal of King Abdulaziz University-Medical Sciences, 14(2), 37-47. 